\title{
Black scabbardfish (Aphanopus carbo Lowe, 1839) in the southern Northeast Atlantic: considerations on its fishery
}

\author{
LEONEL SERRANO GORDO \\ Departamento de Biologia Animal and Centro de Oceanografia, Faculdade de Ciências da Universidade de Lisboa, \\ Bloco C2, Campo Grande, 1749-016 Lisboa, Portugal. E-mail: 1sgordo@fc.ul.pt
}

The black scabbardfish belongs to the Trichiuridae family characterised by: i) an extremely elongate and compressed body with a small forked or hair-like caudal fin; ii) strong teeth, fang-like in the anterior part of the upper jaw; iii) one nostril on each side of snout; and iv) pelvic fins absent or reduced to 1 scale-like spine and 0-2 rudimentary soft rays (Nakamura and Parin, 1993). In the northeast Atlantic, this family includes 3 genera and 5 benthopelagic carnivorous species. Trichiurus lepturus Linnaeus, 1758 and Lepidopus caudatus (Euphrasen, 1788) (the silver scabbardfishes) occur mainly from the English Channel southward to the northwest coast of Africa, including the Mediterranean. They inhabit the continental shelf down to 350-400 m (occasionally $600 \mathrm{~m}$ ) and are commercially exploited (Parin, 1986). The other 3 species are deep-water species, and Benthodesmus simonyi (Steindachner, 1891) is the one that reaches the shallowest water (down to $950 \mathrm{~m}$ ) with a distribution mainly associated with seamounts (Nakamura and Parin, 1993). In the northeast Atlantic the genus Aphanopus has two species (A. carbo and A. intermedius, Parin 1993). Both occur at a wide depth range (from $200 \mathrm{~m}$ to $1700 \mathrm{~m}$ for $A$. carbo and to $1350 \mathrm{~m}$ for A. interme- dius) and have a wide distribution (Nakamura and Parin, 1993), with records in the northwest and east Atlantic and Pacific (only northwest in the case of $A$. carbo). However, in the east Atlantic, A. intermedius has a southern distribution, occurring in the Canary Islands south to Angola, whereas A. carbo has a northern distribution, occurring from Iceland to the Canary Islands (Nakamura and Parin, 1993).

The possible presence of $A$. intermedius in the Portuguese waters has been an object of concern since the beginning of the study of black scabbardfish by Portuguese researchers in the 1990s. In fact, between 1997 and 2000, an initial effort was made to test the presence of A. intermedius in the Portuguese waters but its occurrence was not confirmed in mainland Portugal, Madeira and the Azores. Recently the species was found in a very localised area in the Azores, south of Pico Island (Stefanni and Knutsen, 2007). Stefanni and Knutsen studied two mtDNA regions of black scabbardfish caught in several areas of the NE Atlantic (mainland Portugal, Madeira, the Seine and Sedlo seamounts, the Faraday seamount (mid-Atlantic Ridge) (Fig. 1), six Azores Islands and 3 fishing banks close to the Azores) and concluded that two groups were present: one that included all the individuals 

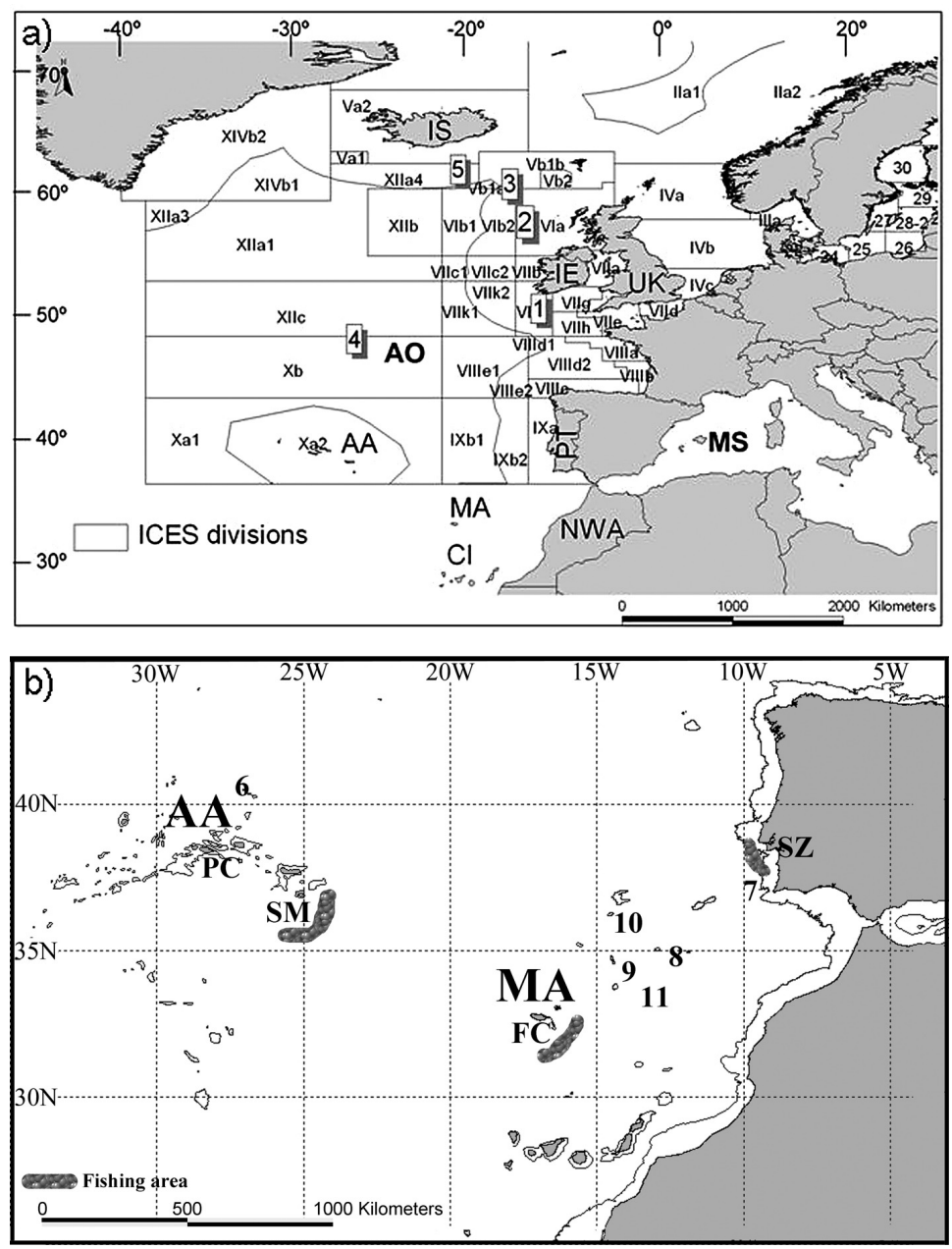

FIG. 1. - a) Map of the northeast Atlantic with the ICES divisions and b) the southern northeast Atlantic with the sampling locations of black scabbardfish and the $1000 \mathrm{~m}$ isobath. AA, Azores Archipelago; AO, Atlantic Ocean; CI, Canary Islands; FC, Funchal; IE, Ireland; IS, Iceland, MA, Madeira Archipelago; MS, Mediterranean Sea; NWA, Northwest Africa; PC, Pico Island; PT, mainland Portugal; SM, Santa Maria Island; SZ, Sesimbra (mainland Portugal); UK, United Kingdom; 1, Porcupine Seabight; 2, Rockall Trough; 3, Hatton Bank; 4, Faraday seamount; 5, Reykjanes Ridge; 6, Sedlo seamount; 7, Gorringe seamount; 8, Ampère seamount; 9, Unicorn bank; 10, Lion seamount; 11, Seine seamount.

from Madeira, mainland Portugal and the Faraday seamount and one that included all the individuals from Pico Island (Azores); the remaining areas had individuals in both groups. One possible explanation put forward by Stefanni and Knutsen for the differences found in the specimens from this second group may be that they belong to A. intermedius instead of A. carbo and therefore the former species could also occur in the Azores archipelago. These two species are morphologically similar: A. intermedius has 102108 vertebrae and 40-44 dorsal fin spines, whereas A. carbo has 97-100 vertebrae and 38-40 dorsal fin spines (Nakamura and Parin, 1993).

In the northeast Atlantic, and especially in its southern area, A carbo has been associated with steady slopes and seamounts (Leite, 1988) that are particularly common in the mid-Atlantic Ridge
(Merrett and Haedrich, 1997) and the Portuguese waters (including Madeira and the Azores) (Fig. 1). This area, and in terms of its hydrology, is influenced by three water masses: the North Atlantic Central Outflow (NACO), the Mediterranean Outflow (MO) and the North Atlantic Deep Outflow (NADO). The NACO is mainly present down to $500-600 \mathrm{~m}$ depth and the NADO predominates below $1400 \mathrm{~m}$ (although it is mostly present under $2000 \mathrm{~m}$ ); both have a highly significant correlation between salinity and temperature (Pissarra et al., 1983). The influence of the MO is present at depths lower than $600 \mathrm{~m}$ and down to $2000 \mathrm{~m}$ and does not show a correlation between salinity and temperature (Pissarra et al., 1983). This outflow is characterised by relatively stable but high salinities and temperatures (respectively 36.5 and $11.9^{\circ} \mathrm{C}$; Anon., 2000; Pissarra 
et al., 1983) in relation to the depth at which it is found. After passing the Gibraltar strait, it divides into a southern component that reaches Madeira waters and a northern component that extends into the deep water off Portugal and can be detected in the Porcupine Seabight (Rice et al., 1991) and Rockall Trough (Ellett et al., 1986). It has several cores although the two most important lie at $800 \mathrm{~m}$ (upper core) and $1200 \mathrm{~m}$ (lower core) (Ambar and Howe, 1979). This interval corresponds to the depth at which the black scabbardfish is mainly caught, so the black scabbardfish is commonly associated with MO. In fact, experimental research cruises carried out between 1979 and 1987 by the National Institute of Fisheries Research (IPIMAR) showed that the highest abundance was achieved in the Seine, Lion, Gorringe, Ampère and Unicorn seamounts (northeast of Madeira Archipelago) (Leite, 1988), an area where the influence of the MO was higher ( $\geq 68 \%$ in the Ampère and Gorringe seamounts) than in the waters around Madeira Island, where the MO influence is around 40\% (Pissarra et al., 1983) and the fish abundance is lower.

The fishery of black scabbardfish in Madeira Island dates back to the 17th century and, although its origin is obscure, it is thought to have arisen as a result of the fishery for deep water sharks (Merrett and Haedrich, 1997). Fishing is traditionally carried out at night, and for several decades this was the only fishery targeting black scabbardfish in the northeast Atlantic, using simple handlines at the beginning and longlines later on (20th century) (Bordalo-Machado and Figueiredo, 2008). The traditional vessels were open, wooden ones that were 7-8 $\mathrm{m}$ long and $3 \mathrm{~m}$ wide, with no shelter (Leite, 1988), requiring a crew of 8 men. Fishing was done using drifting vertical longlines that were totally made of hemp fibre. Each longline was made up of several lines connected to each other, each one with 180 hooks (Leite, 1988). This traditional method was first replaced by a similar set design using synthetic monofilament, and more recently the vertical longline was replaced by a horizontal longline supporting between 4000 and 5000 hooks (Martins and Ferreira, 1995). The bait used includes sardine (Sardina pilchardus), Spanish mackerel (Scomber colias), horse mackerel (Trachurus picturatus) and squid (Ommastrephes pteropus and $O$. bartrami), the latter being by far the best bait for black scabbardfish fishery (Leite, 1988).

The fishery for black scabbardfish on mainland Portugal started in 1983 at grounds around Sesim- bra port following a series of exploratory surveys conducted by the IPIMAR in close collaboration with the fisheries sector (more than $95 \%$ of the landings of black scabbardfish still occur here). At the beginning of the fishery, the fleet comprised small artisanal vessels, having an average length over all (LOA) of around $11 \mathrm{~m}$ and an average gross registered tonnage of $c a$. 16. Since then, the fleet has undergone technological improvements, indicated by the increase in average values for engine power, tonnage and LOA, but it maintains its artisanal characteristics. The median number of fishermen that compose each vessel's crew is 6 (range 1-10) and 8 (range 7-12) for land and sea crews, respectively. Land crews are often smaller than the sea crews, because in some vessels most of the latter carry out both land and sea functions, which reduce the need to hire personnel to work on land-based operations (Bordalo-Machado and Figueiredo, 2008). The total number of hooks used by fishing gear has increased over time. Initially, the longlines had 3600-4000 hooks (Martins et al., 1989), compared with 4800 to 5400 in 1996 (Henriques, 1997) and 4000 to 10000 in 2004 (Bordalo-Machado and Figueiredo, 2008).

In northern Europe, the species has been mainly captured by a bottom trawl multi-species fisheries operating in ICES subareas V, VI, VII and XII (Fig. 1). French fisheries accounted for almost $90 \%$ of the combined landings in subareas VI and VII and $35 \%$ of the landings in Division $\mathrm{Vb}$ in the period 1988-2005 (ICES 2006). The Faröe islands reported $62 \%$ of the landings in Division $\mathrm{Vb}$ and $49 \%$ from subarea XII (ICES 2006). In addition to black scabbardfish, this multi-species fishery also captures the roundnose grenadier (Coryphaenoides rupestris), deep-sea sharks (mainly Portuguese dogfish, Centroscymnus coelolepis and Leaf-scale gulper shark, Centrophorus squamosus), blue ling (Molva dypterygia), ling (Molva molva), saite (Pollachius virens) and monkfish (Lophius piscatorius, L. budegassa) (Holley and Marchal, 2004). For the period 1999-2003, French bottom trawlers-fewer in number than the Portuguese longliners operating in the south-reported a larger amount (nearly 50\% more) of black scabbardfish landings (BordaloMachado and Figueiredo, 2008).

At present, the fleet targeting black scabbardfish in Portuguese waters still displays artisanal features, while more industrialised fleets such as the large (49-55 m) and powerful (ca. $2000 \mathrm{Hp}$ ) French deepwater freezer trawlers continue to operate in 


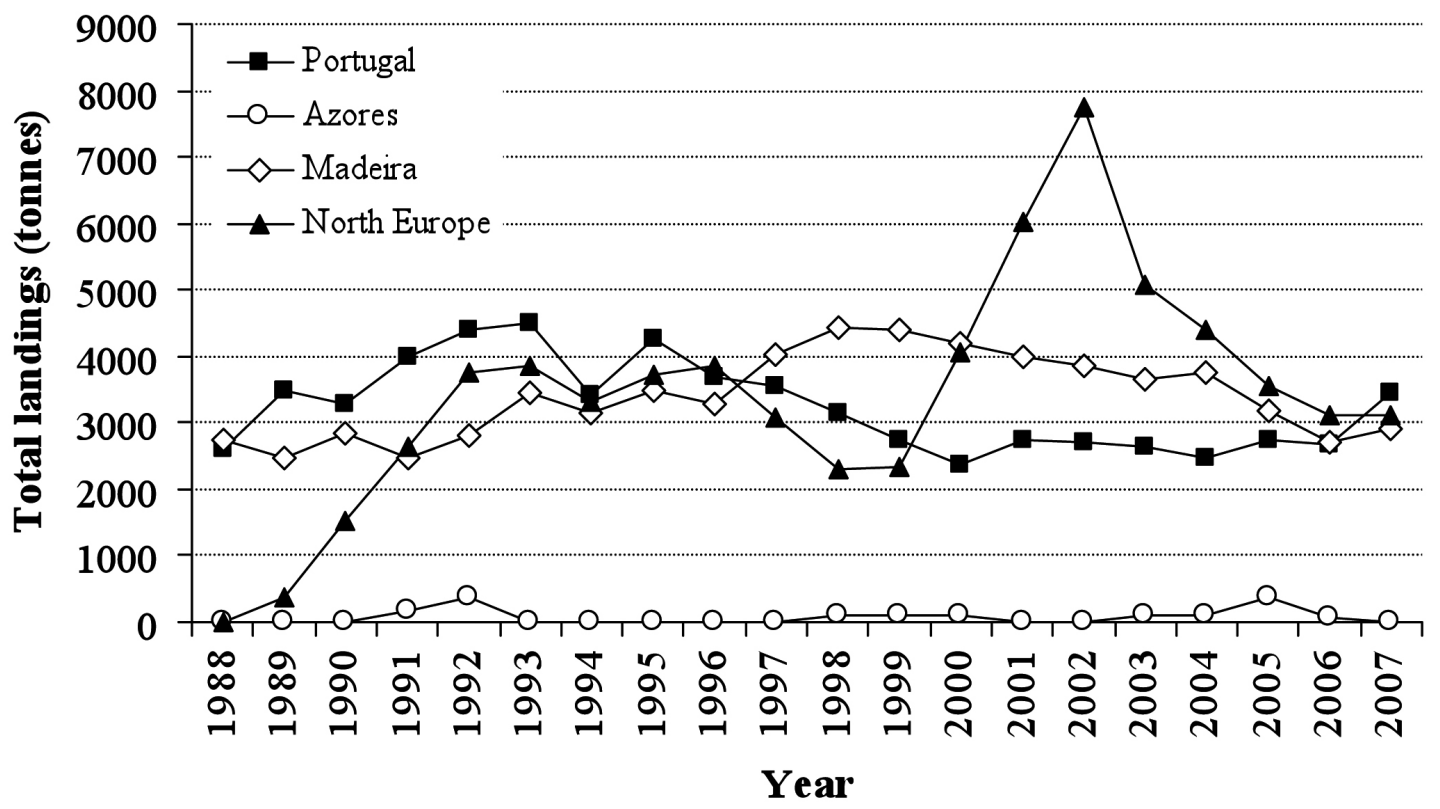

FIG. 2. - Total landings (tonnes) reported by mainland Portugal, Madeira, the Azores and northern Europe (subareas II, IV, V, VI and VII combined) for the last 20-year period. Sources for Madeira data: DREM (2008); Other data: ICES (2008).

northern European waters (ICES, 2006). This artisanal fishery is typical of Portuguese communities that depend on the sea for their livelihood, where the product is marketed fresh and the markets are mainly local. It is a traditional fishery with few technological innovations and is also based on the family labour force. It is embedded in the cultural activity of the community and the economic, social, political and ecological aspects contrast with those to be found in the highly developed trawl fisheries of northern European countries: e.g. traditional vs. modern, artisanal vs. industrial, family vs. company and conservation vs. over-exploitation.

Figure 2 shows the total landings (tonnes) reported in mainland Portugal, Madeira, the Azores and northern Europe (subareas II, IV, V, VI and VII combined) for the last 20-year period. As can be seen, in mainland Portugal an increasing trend was observed between 1988 and 1993, followed by a slight decrease until 2000 , and since then the landings have been stable around 2700 tonnes per year. In Madeira, the first decade was marked by an increasing trend toward a maximum of 4430 tonnes recorded in 1998, whereas in the second decade a decreasing trend can be observed to reach a value close to 2900 tonnes in 2007. In the Azores, there is only an exploratory fishery, so landings recorded in the whole period were lower. In northern Europe two main peaks can be seen: the first between 1992 and 1996 and the second in 2002. From this year onwards, a marked decreased can be observed until 2007.

The stability of the landings in the last decade in ICES Division IXa, the sharp decrease in the northern European areas, and the generalised absence of biological information on the species led the International Council for the Exploration of the Sea to establish (arbitrarily) the existence of a single stock in the northeast Atlantic, although divided into two components: north and south (ICES, 2007). The north component corresponds to subareas V, VI, VII and XII and the south component to subarea IX.

This uncertainties in the stock structure led researches from five Portuguese institutions from Mainland Portugal, the Azores and Madeira to combine efforts to try to define the most appropriate strategy for managing this resource in the southern northeast Atlantic.

The APHACARBO project partially funded by the Fundação para a Ciência e Tecnologia was the result of these efforts and had two main goals:

1. To clearly identify the stock structure(s) through a combination of methodologies.

2. To assess the biochemical composition and bioaccumulation levels to assure fish quality with respect to EU standards.

The possible presence of two morphologically similar species in the distribution area required sampling to be done with great care. Furthermore, the research team knew that some colleagues from Ma- 
deira and the Azores have combined efforts to verify the occurrence of $A$. intermedius in the Portuguese waters and its occurrence has in fact been confirmed in Pico Island (Azores) and Madeira landings but never in mainland Portugal (Sara Reis, pers. comm.). Therefore, in the APHACARBO project, although the specimens in the Azores have been mainly caught in Santa Maria (where the percentage of $A$. intermedius is lower), they were morphologically analysed to be sure that only A. carbo were present. In Madeira waters it was known that black scabbardfish abundance had decreased in the last few years and the fishermen had moved southwards (to the Canary Islands waters, where A. intermedius is more common) to obtain greater income. Therefore, the increase in the percentage of A. intermedius (which in some samples could reach $20 \%$ [Sara Reis, pers. comm.]) in the landings is due to the capture of both species south of Madeira waters with larger vessels that can make longer trips. Therefore, to minimise the mixture effect, all samples used in the project were obtained from small vessels that operate near Madeira in daily trips. Moreover, an effort was made to determine whether specimens from $A$. intermedius were present in the samples and every individual morphologically analysed belonged to A. carbo.

In this volume, Section 1 deals with the stock structure following a holistic approach and including the ensuing thematic areas:

- Reproduction, discussing the spawning strategies (Neves et al., 2009).

- Age and growth, including both ageing techniques and age and growth (Vieira et al., 2009).

- Morphometric studies, namely otolith shape analysis (Farias et al., 2009).

- Parasites as biological tags in population studies (Santos et al., 2009).

- Fishery description, considering data on Landings Per Unit of Effort and discards (Bordalo-Machado et al., 2009).

- Contaminants, analysing the levels of cadmium, lead and mercury (Costa et al., 2009).

- An integrative paper with the comparative analysis of the different techniques used (Gordo et al., 2009).

Section 2 deals with fish quality and includes the following issues:

- Nutritional value, analysing the results of the proximate chemical composition, fatty acid profile, cholesterol, amino acids and minerals in raw fish but considering the effect of frying and grilling on the constituents (Bandarra et al., 2009).

- Parasite (Anisakis) infestation, considering the risks for human consumption (Cruz et al., 2009).

\section{REFERENCES}

Âmbar, I. and M.R. Howe. - 1979. Observation of the Mediterranean outflow. I. Mixing in the Mediterranean outflow. Deep Sea Res., 26A: 535-554.

Bandarra, N.M., I. Batista and M.L. Nunes. - 2009. Nutritional value of raw, fried and grilled black scabbardfish (Aphanopus carbo Lowe, 1839). Sci. Mar., 73S2: 105-113.

Bordalo-Machado, P. and I. Figueiredo. - 2008. The fishery for black scabbardfish (Aphanopus carbo Lowe, 1839) in the Portuguese continental slope. Rev. Fish Biol. Fisheries, DOI 10.1007/s11160-008-9089-7. 19p.

Bordalo-Machado, P., A.C. Fernandes, I. Figueiredo, O. Moura, S. Reis, G. Pestana and L.S. Gordo. - 2009. The black scabbardfish (Aphanopus carbo Lowe, 1839) fisheries from the Portuguese EEZ. Sci. Mar., 73S2: 63-76.

Costa, V., H.M. Lourenço, I. Figueiredo, L. Carvalho, H. Lopes, I. Farias, L. Pires, C. Afonso, A.R. Vieira, M.L. Nunes and L.S. Gordo. - 2009. Mercury cadmium and lead in black scabbardfish, Aphanopus carbo Lowe, 1839, from mainland Portugal, Azores and Madeira Archipelagos. Sci. Mar., 73S2: 77-88.

Cruz, C., A. Saraiva, M.J. Santos, J.C. Eiras, C. Ventura, J.P. Soares and M. Hermida. - 2009. Anisakis (Nematoda, Anisakidae) infestation in Aphanopus carbo (Osteichthyes: Trichiuridae) from Portuguese waters. Sci. Mar., 73S2: 115-120.

Direcção Regional de Estatística da Madeira (DREM). - 2008. Série Retrospectiva. Estatística da Agricultura e Pescas (1976-2007). Secretaria Regional do Plano e Finanças, Região Autónoma da Madeira, $25 \mathrm{pp}$.

Ellett, D.J., A. Edwards and R. Bowers. - 1986. The hydrography of the Rockall Channel - an overview. Proc. R. Soc. Edinb., 88B: 61-81.

Farias, I., A.R. Vieira, L.S. Gordo and I. Figueiredo. - 2009. Otolith shape analysis as a tool for population discrimination of black scabbardfish (Aphanopus carbo Lowe, 1839) in Portuguese waters. Sci. Mar., 73S2: 47-53.

Gordo L.S., I. Baptista, L. Carvalho, V. Costa, C. Cruz, J.C. Eiras, I. Farias, I. Figueiredo, H. Lourenço, P. Bordalo-Machado, A. Neves, M.L. Nunes, S. Reis, M.J. Santos, A. Saraiva and A.R. Vieira. - 2009. Stock structure of black scabbardfish (Aphanopus carbo Lowe, 1839) in the southern North East Atlantic. Sci. Mar., 73S2: 89-101.

Henriques, V. - 1997. Final report of Sub-task 1.3: description of Portuguese deep-water fisheries. Final report of EC (FAIR) research project, specific RTD programme, CT95- 655, Developing Deep-water Fisheries, 9 pp.

Holley, J-F. and P. Marchal. - 2004. Fishing strategy development under changing conditions: examples from the French offshore fleet fishing in the North Atlantic. ICES J. Mar. Sci., 61(8):1410-1431.

ICES. - 2006. Report of the Working Group on the Biology and Assessment of Deep-sea Fisheries Resources (WGDEEP). ICES C.M. 2006/ACFM,28: 1-504

ICES. - 2007. Report of the Working Group on the Biology and Assessment of Deep-sea Fisheries Resources (WGDEEP). ICES C.M. 2007/ACFM, 20: 1-478.

ICES. - 2008. Report of the Working Group on the Biology and Assessment of Deep-sea Fisheries Resources (WGDEEP). ICES C.M. 2008/ACOM, 14: 1-531.

Leite, A.M. - 1988. The deep-sea fishery of the black scabbard fish Aphanopus carbo Lowe, 1839 in Madeira Island waters. Proc. World Symp. Fishing Gear and Fishing Vessel Design, Marine Institute St. John's, Newfoundland, Canada: 240-243.

Martins, M.R, M.M. Martins and F. Cardador. - 1989. Portuguese fishery of black scabbard fish (Aphanopus carbo Lowe, 1839) off Sesimbra waters. ICES Dem. Fish Comm. CM1989/G,38: 1-29.

Martins, R. and C. Ferreira. - 1995. Line fishing for black scab- 
bardfish (Aphnaopus carbo Lowe, 1839) and other deep water species in the eastern Atlantic to the north of Madeira. In: A.G Hopper. (ed.), Deep-water Fisheries of the North Atlantic Oceanic Slope, pp. 323-335. Kluwer Academic Publishers.

Merrett, N. R. and R.L. Haedrich. - 1997. Deep-sea demersal fish and fisheries. Chapman and Hall, London.

Nakamura, I. and N.V. Parin. - 1993. FAO species catalogue. Vol 15. Snake mackerels and cutlassfishes of the world (families Gempylidae and Trichiuridae). An annotated and illustrated catalogue of the snake mackerels, snoeks, escolars, gemfishes, sackfishes, domine, oilfishes, cutlassfishes, scabbardfishes, hairtails and frostfishes known to date. FAO Fish. Synop., 125 (15): $1-136$

Neves, A., A.R. Vieira, I. Farias, I. Figueiredo, V. Sequeira and L.S. Gordo. - 2009. Reproductive strategies in black scabbardfish, Aphanopus carbo (Teleostei: Trichiuridae). Sci. Mar., 73S2: 19-31.

Parin, N.V. - 1986. Trichiuridae. In: P.J.P. Whitehead, M.-L. Bauchot, J.-C. Hureau, J. Nielsen and E. Tortonese (eds.), Fishes of the North-eastern Atlantic and the Mediterranean, pp. 976-980. Unesco, Paris.

Pissarra, J.L., M.H. Cavaco and A.M. Leite. - 1983. Caracterização oceanográfica na região da Madeira: determinação das massas de água no "núcleo de água mediterrânica". Bol. Inst. Nac. Invest. Pescas, 10: 65-80.

Rice, A.L., D.S.M. Billett, M.H. Thurston and R.S. Lampitt. - 1991. The Institute of Oceanographic Sciences biology programme in the Porcupine Seabight: background and general introduction. J. Mar. Biol. Assoc. U.K., 71: 281-310.

Santos, M.J., A. Saraiva, C. Cruz, J.C. Eiras, M. Hermida, C. Ventura and J.P. Soares. - 2009. Use of parasites as biological tags in stock identification of black scabbard fish, Aphanopus carbo Lowe, 1839 (Osteichthyes, Trichiuridae) from Portuguese waters. Sci. Mar., 73S2:

Stefanni, S. and H. Knutsen. - 2007. Phylogeography and demographic history of the deep-sea fish Aphanopus carbo (Lowe, 1839) in the NE Atlantic: vicariance followed by secondary contact or speciation? Mol. Phyl. Evol., 42: 38-46.

Vieira, A.R., I. Figueiredo, I. Farias, A. Neves, B. Morales-Nin, V. Sequeira, M.R.Martins and L.S. Gordo. - 2009. Age and growth of black scabbardfish (Aphanopus carbo Lowe, 1839) in the southern NE Atlantic. Sci. Mar., 73S2: 33-46.

Scient. ed.: M.P. Olivar.

Received December 22, 2008. Accepted November 3, 2009.

Published online December 22, 2009. 